\title{
SEQUÊNCIA DIDÁTICA PARA A PROMOÇÃO DE ESTUDO PRÁTICO E MULTIDISCIPLINAR COM MATERIAIS ACESSÍVEIS
}

\author{
Sharise Beatriz R. Berton ${ }^{\mathrm{a}, \mathrm{c}, \text {, }(1)}$, Milena P. Ferreira ${ }^{\mathrm{b}}$, Edmilson Antonio Canesin ${ }^{\mathrm{c}}$, Rúbia Michele Suzuki ${ }^{\mathrm{c}}$, Alessandro \\ Francisco Martins ${ }^{c}$, Elton G. Bonaféc e Makoto Matsushita ${ }^{a}$ \\ aDepartamento de Química Analítica, Universidade Estadual de Maringá, 87020-900 Maringá - PR, Brasil \\ bepartamento de Química, Universidade Estadual de Londrina, 86057-970 Londrina - PR, Brasil \\ 'Departamento de Química Analítica, Universidade Tecnológica Federal do Paraná, 86812-460 Apucarana - PR, Brasil
}

Recebido em 27/12/2019; aceito em 16/01/2020; publicado na web em 31/03/2020

\begin{abstract}
DIDACTIC SEQUENCE FOR THE PROMOTION OF PRACTICAL AND MULTIDISCIPLINARY STUDY WITH ACCESSIBLE MATERIALS. Innovation and multidisciplinarity are the way to accelerate improvements in education, as well as the search for contextualized content. The multidisciplinarity between chemistry and Biology, allows to explore various contents, one of them is the environment. Works that offer alternatives to simpler experiments are of great help professors. In this context, this study suggests a didactic sequence using easily accessible materials to address chemical and Microbiological concepts of soil. The proposal is aimed at high school students and early undergraduate students. The contents were: hydrogen potentials $(\mathrm{pH})$, mixture separation methods, soil liquid and gas phases and soil microbial population extraction involving bacterial DNA. Thus, the work shows a low cost alternative for the teaching of concepts related to soil, being a contextualized, multidisciplinary, dynamic and attractive proposal.
\end{abstract}

Keywords: chemical soil analysis; biological soil analysis; multidisciplinarity; bacterial DNA; easy access materials.

\section{INTRODUÇÃO}

A aula prática desperta grande interesse por parte dos alunos, pois eles saem do ambiente tradicional e partem para um convívio diferente e muito envolvente; um meio onde os alunos adquirem a possibilidade de um contato direto com os fenômenos, manipulando diferentes materiais e equipamentos, observando o crescimento de organismos e o meio onde vivem, contribuindo na internalização do conhecimento. ${ }^{1,2}$ Esse meio pode, então, reforçar os aspectos macroscópicos do fenômeno. Já a aula teórica leva o aluno a uma reflexão sobre os aspectos microscópicos. Esses dois métodos, em conjunto - teórico e prático - atingem o propósito fundamental do ensino que é construir o conhecimento para a formação do cidadão crítico, essencial para a criação de um pensamento químico. ${ }^{2,3}$

Ciências da Natureza agregam, atualmente, um novo conjunto de ferramentas e técnicas disponíveis para a investigação do solo. ${ }^{3,4}$ Devido à complexidade do abstrato no estudo de Ciências da Natureza, percebe-se, porém, a carência de apreensão por parte dos discentes. ${ }^{5}$ Nesse contexto, faz-se necessário o uso de mecanismos auxiliadores no processo de ensino como a multidisciplinaridade e assimilação.

A literatura em geral, classifica a pesquisa, envolvendo professores de diferentes disciplinas como os pertencentes a três principais categorias: multidisciplinar, interdisciplinar e transdisciplinar. ${ }^{5,6}$ Stokols ${ }^{7}$ fornece uma distinção desses diferentes termos. O "multidisciplinar" ocorre quando professores de diferentes disciplinas trabalham de forma independente e sequencial, porém, cada um em sua perspectiva específica, envolvendo sua disciplina, resolvendo assim um problema comum. Souza e Leite ${ }^{8}$ apontam a multidisciplinaridade como um grupamento de disciplinas que estudam, simultaneamente, um determinado assunto, sem o envolvimento efetivo entre si.

Já, no termo "interdisciplinar", os professores trabalham em conjunto, porém cada um em perspectiva própria, dentro de suas respectivas disciplinas para resolver um problema comum. ${ }^{8}$ Por último, em "transdisciplinar" os professores trabalham em conjunto

*e-mail: sharise_beatriz@hotmail.com para desenvolver uma estrutura conceitual compartilhada que reúne teorias, conceitos e métodos específicos da disciplina para resolver um problema comum. ${ }^{7}$

Ferreira ${ }^{9}$ propõe estratégias pedagógicas multidisciplinares que valorizem o prazer, a emoção, a imaginação, a criatividade e a intuição do aluno. Propõe, também, o uso de recursos didáticos, conciliando a Ciência e a Arte no ensino, criando mecanismos de conexão, nos alunos, com seus propósitos de aprendizagem.

Dentre os mecanismos, a atividade experimental e a sequência didática são meios promissores. ${ }^{6,7}$

Professores, tanto da Química como da Biologia, estão conscientes da atual realidade da educação em relação à disponibilidade de laboratórios equipados para o desenvolvimento de aulas práticas. ${ }^{10,11}$ A difusão de aulas requer recursos didáticos que auxiliem no processo ensino-aprendizagem. Por isso, o desenvolvimento e a introdução de estratégias apropriadas para a efetivação de uma aula prática, utilizando equipamentos de fácil acesso, torna-se um bem crucial em termos de eficiência de recursos. ${ }^{12-14}$

Além disso, a atividade experimental precisa ser direcionada de forma consciente em relação aos perigos e emergências que possam ser evidenciados no decorrer da mesma. ${ }^{15}$

Nesse contexto, a utilização de recursos didáticos tem também um papel muito importante. ${ }^{15}$ Além das aulas experimentais, com materiais alternativos (como os que foram utilizados no presente trabalho), o uso de softwares educacionais, a elaboração de mapas conceituais, o uso de jogos didáticos - cartas, tabuleiro, jogos midiáticos, aulas que utilizam tecnologias digitais da informação e da comunicação - também são extremamente importantes. ${ }^{16}$

Para o desenvolvimento de uma atividade experimental, utilizam-se as sequências didáticas - procedimentos encadeados de passos ou etapas interligadas - tornando o processo ensino-aprendizado mais eficiente. Essas etapas são:

- Exploração de Conceitos (um tema é escolhido e um problema a ser investigado é formulado);

- Investigação do Conceito (faz-se um levantamento de informações sobre o assunto e se formulam hipóteses); 
- Solução de Problemas (realizam-se experimentações, analisam-se os resultados obtidos e se estabelecem conclusões);

- Avaliação (avalia-se o que foi investigado). ${ }^{17,18}$

Santos e Zanello ${ }^{19}$ analisaram os aspectos físico-químicos da água do Rio Canguiri e do solo circunvizinho ao rio com alunos do ensino médio. A aula experimental propiciou aos educandos o contato direto com o objeto do estudo, por meio da manipulação de equipamentos, reagentes, vidrarias laboratoriais, além de discussões e reflexões sobre a importância do solo não apenas como recurso agropecuário, mas como elemento passível de cuidados e preocupações.

Fisher et al. ${ }^{20}$ fornecem informações que envolvem a problematização do manejo do solo para a construção do conhecimento; em seguida, os autores extrapolam para uma educação multidisciplinar, possibilitando ao aluno observar toda a gama de possibilidades desse manejo.

No trabalho de Silva et al.,${ }^{21}$ foi aplicada uma sequência didática com o uso de materiais alternativos, de baixo custo e de fácil acesso, como: seringas, água oxigenada, prego, água sanitária - entre outros materiais - para a realização de experimentos de Química, relacionados aos temas de Cinética Química e Eletroquímica. Oliveira, Resende Filho e Andrade ${ }^{22}$ desenvolveram um experimento para identificação de ácido salicílico em produtos dermatológicos, utilizando-se de materiais de fácil acesso, baixo custo e recicláveis.

O uso, então, de aulas práticas com tais materiais e uma sequência didática multidisciplinar, para o aprendizado tanto de Química como de Microbiologia e/ou da Biologia, tornam-se essenciais, uma vez que essas disciplinas são consideradas o foco da educação em muitos níveis, desde o ensino fundamental até estudos de graduação e de pós-graduação..$^{23,24}$

\section{Abordagens temáticas para o ensino de Química}

Os blocos temáticos propostos para o ensino médio $\left(1^{\circ}, 2^{\circ} \mathrm{e}\right.$ $3^{\circ}$ anos), relacionados às disciplinas de Química e Biologia, de maneira geral são respectivamente: matéria e sua natureza (mistura, método de separação, fenômeno físico e químico), potencial hidrogeniônico $(\mathrm{pH})$, vírus e bactérias, substâncias orgânicas e inorgânicas (classificações das substâncias; funções das substâncias; estrutura das substâncias), engenharia genética, entre outros conteúdos. $^{25}$

Já, em um curso superior em Química, as disciplinas ofertadas nos anos iniciais variam de acordo com a universidade, porém de maneira geral os blocos temáticos relacionados à disciplina de Química geral estão relacionados com o estudo de separação de misturas, soluções ácidas e básicas, ligações químicas, periodicidade química, entre outros. E os blocos temáticos para a disciplina de Microbiologia estão relacionados com a morfologia e citologia bacteriana, crescimento bacteriano, nutrição, reprodução, genética, entre outros.

Esses conteúdos podem ser apresentados, utilizando o meio ambiente como partida, onde a realização de experimentos para demonstrar na prática como se faz uma coleta adequada de amostra, o significado do pH para a mesma, os métodos de separação de uma mistura, além da determinação da população microbiana do solo e a extração do DNA bacteriano, podem ser uma ótima maneira para o aprendizado dos temas demonstrados anteriormente. ${ }^{26}$

Juntamente com o conteúdo inicial sobre meio ambiente, é possível introduzir o assunto sobre as fases líquida e gasosa do solo, indicando que a gasosa, por exemplo, é importante tanto para os microrganismos ali presentes quanto para as raízes das plantas.

Procedimentos de amostragens também são interessantes de serem apresentados aos alunos como mencionado anteriormente, indicando a importância de se fazer uma amostragem correta, pois ela representará o todo. É importante deixar claro, nesse momento, que amostras destinadas a análises Químicas não necessitam de materiais estéreis como é exigido nas amostras destinadas as análises Microbiológicas. ${ }^{27}$

Após essas abordagens, os métodos de separação de misturas devem ser introduzidos, dando-se ênfase na catação e peneiramento, com o objetivo de implementá-los posteriormente.

O conteúdo relacionado ao potencial hidrogeniônico $(\mathrm{pH})$ também é um conteúdo importante a ser introduzido em aulas posteriores, aplicando a multidisciplinaridade, indicando que o mesmo é influenciado pela composição do solo em ácidos e bases, e também é importante tanto para o crescimento de plantas como ao controle da abundância de algas, ${ }^{28}$ bactérias ${ }^{29}$ e fungos.

Com esse tema, é possível também introduzir o conteúdo relacionado à população microbiana do solo e, consequentemente, o conteúdo relacionado à engenharia genética. Sugere-se trabalhar conteúdos sobre a resistência aos antibióticos, pois este é um elemento genético muito importante que relaciona a existência dos genes contidos nos microrganismos com diferentes mecanismos bioquímicos que impedem a ação das drogas. ${ }^{27,30}$ Essa resistência pode ser originada por diversos meios, mutações, erros de cópias na sequência base que forma o DNA cromossômico, além da importação dos genes causadores do fenômeno. ${ }^{27}$

As abordagens temáticas no ensino de Química e Biologia tanto no ensino médio como em anos iniciais do ensino superior, desenvolvem valores e atitudes que propiciam a discussão das questões ambientais, econômicas, éticas e sociais. ${ }^{23,31}$

Essas disciplinas geralmente são trabalhadas separadamente, porém, sabe-se que essa fragmentação do conhecimento desfavorece a construção de um ensino-aprendizado de qualidade. Além disso, essa fragmentação muitas vezes leva ao desinteresse por parte do aluno, induzindo ainda a falsa impressão de que o conhecimento de um modo geral é compartimentalizado, fazendo com que o discente não estabeleça relações entre eles. ${ }^{25}$ Por isso, os conteúdos abordados em sala de aula, quando possível, sugerem-se partir de temas que permitam a multidisciplinaridade entre diferentes saberes. ${ }^{31,26}$

O meio ambiente, em particular o meio terrestre, é um tema rico em conteúdo. A partir dele podem ser estudadas as várias fontes de elementos naturais que são essenciais para a vida do planeta, para a produção de oxigênio fornecida por meio da fotossíntese realizada pelas plantas e o fornecimento de alimentos por parte da agricultura e pecuária. Além disso, podem ser abordadas questões como agrotóxicos, fertilizantes, alimentos transgênicos e mutação genética, dentre muitos outros assuntos. Devido a isso, a multidisciplinaridade torna-se possível e indispensável quando relacionada às disciplinas de Química e Biologia. ${ }^{32,26}$

Esse fato proporciona aos alunos a oportunidade de um contato direto com o solo, além de vislumbrar a importância de análises químicas e microbiológicas/biológicas e sua influência com o nosso dia a dia. Esse contexto contribui ainda para a formação de um cidadão responsável e consciente frente às atitudes tomadas no futuro. ${ }^{33}$

Nesse sentido, o presente estudo relata o ensino na área de Química e Microbiologia/Biologia por meio de uma investigação científica: sequência didática, envolvendo experimentos multidisciplinares relacionados à avaliação do solo, utilizando materiais de fácil acesso, para que possa ser aplicada em aulas experimentais tanto no ensino médio como nos anos iniciais do curso de graduação.

\section{EXPERIMENTAL}

Para proporcionar efetividade confiável ao desenvolvimento de uma aula prática, os procedimentos de sequência didática foram aplicados e baseados em dinâmica específica sistematizada em quatro etapas distintas: exploração de conceitos, investigação do conceito, 
solução de problemas e a avaliação. ${ }^{18,34}$ Essa opção foi escolhida por apresentar uma sustentação teórica do ponto de vista cognitivo.

Para tal, os experimentos foram realizados com cunho demonstrativo para vislumbrar a compreensão de argumentos científicos juntamente com materiais de fácil acesso.

\section{Coleta de amostras}

Em nível de pesquisa demonstrativa, as amostras de solo, do presente trabalho, foram coletadas na cidade de Apucarana - PR, totalizando aproximadamente $400 \mathrm{~g}$ de solo em cada um dos quatro pontos, escolhidos aleatoriamente (o experimento foi realizado em triplicata).

A coleta foi realizada por meio da retirada da camada superficial do solo até no máximo $20 \mathrm{~cm}$ de profundidade. Essas foram acondicionadas, separadamente, em duas embalagens plásticas e numeradas por ponto de coleta. Uma embalagem foi destinada às análises químicas e outra destinada para as análises microbiológicas, sendo estas previamente tratadas externamente com álcool etílico hidratado $70^{\circ}$ INPM (Instituto Nacional de Pesos e Medidas) e com vedação. No presente trabalho, foram utilizadas embalagens com dimensões de $24 \mathrm{~cm}$ x $8 \mathrm{~cm}$, sendo obtidas facilmente em sites ou lojas de embalagens que trabalham com esse tipo de produto, e possuem baixo custo, cerca de $\mathrm{R} \$ 0,70$ por unidade. Para a coleta, fez-se necessária a utilização de luvas e máscara para que não ocorresse contaminação cruzada.

Após a coleta, as amostras foram acondicionadas em caixa isotérmica contendo gelo e encaminhadas para o laboratório de pesquisa da Universidade Tecnológica Federal do Paraná (UTFPR), campus Apucarana.

Para o estudo em sala de aula, sugere-se que os alunos coletem as amostras de solo em suas próprias escolas, universidade, residências ou, ainda, próximo a elas.

\section{Sugestões}

O professor poderá propor a quantidade de pontos de coletas a serem estudadas pelos alunos, contanto que esse número seja maior ou igual a três, distintos, para realizar uma melhor e ideal comparação entre os mesmos.

Propõem-se, também, que os alunos façam uma busca sazonal anterior a coleta, além da realização de um checklist, para que os mesmos não sejam surpreendidos no momento da coleta.

Propõem-se ainda, que os alunos observem o ambiente onde pretendem coletar as amostras de solo, pois, além da observação, é interessante que os alunos coletem e organizem dados sobre o ambiente e construam um conjunto de imagens e significados, sendo, então, após esta construção, recolhidas as amostras.

$\mathrm{Na}$ área urbana, propõem-se fazer um levantamento de campo das condições sanitárias locais, por meio de pesquisas relacionadas com a coleta e destinação final de efluentes líquidos e resíduos sólidos, para então poder relacioná-los com a quantidade de microrganismos encontrados e também com o pH do solo.

$\mathrm{Na}$ área agrícola também é importante avaliar, por exemplo, o manejo do solo; práticas de preparo do mesmo para plantio; o uso de fertilizantes (como controle de pragas e doenças); e verificação se há ou não queima de resíduos culturais.

\section{Análise Química e/ou Física do solo}

\section{Método de separação de mistura: catação}

Todas as amostras coletadas no presente trabalho foram separadas pelo método de catação, exceto as destinadas as análises microbiológicas.
Sugestões

Para a separação de misturas existem diversos métodos, como: catação, levigação, flotação, peneiração, ventilação, entre outros. ${ }^{35}$ Esses conceitos devem ser introduzidos anteriormente à aplicação da prática.

No presente trabalho, em nível de demonstração, utilizou-se o método de catação, porém o método de peneiração também pode ser utilizado.

Esses métodos têm como objetivo o pré-processamento da amostra contra possíveis interferentes, como: pedregulhos, folhas e outros sólidos que não sejam propriamente o solo, para que não venham a interferir nas etapas subsequentes. É importante salientar que esse método (catação) foi aplicado apenas para $200 \mathrm{~g}$ das amostras de cada ponto, pois as demais amostras foram dedicadas exclusivamente para ensaios microbiológicos, por isso foram coletadas em embalagens separadas.

O princípio do método de catação se baseia em recolher com o auxílio de uma pinça comum ou até mesmo com as mãos, todos os componentes impuros presentes na amostra. Após essa etapa, cada aluno deverá anotar quais foram as impurezas perceptíveis a olho nu presentes no solo, e o professor, com os alunos, poderão desenvolver um debate sobre o que foi encontrado.

\section{Verificação das fases líquida e gasosa do solo}

A distinção entre as fases do solo pode ser percebida pela eliminação das bolhas de ar que saem da porosidade do solo, quando imerso em água, chamada assim de fase gasosa.

Esse procedimento consiste em imergir o solo, de preferência ainda em torrão, em aproximadamente $15,0 \mathrm{~mL}$ de água em um tubo de ensaio e, na falta deste, pode-se utilizar um recipiente transparente. Em seguida, observar e anotar o que acontece no decorrer do processo (liberação de gás, esfacelamento e tempo de esfacelamento do torrão).

A fase líquida forma a solução do solo onde se encontram elementos químicos, observa-se então a cor da água no fim do processo. ${ }^{36,37}$

\section{Extrato de repolho roxo usado como indicador universal de pH} para análise de solo

Para a determinação do $\mathrm{pH}$ do solo, foi utilizado um indicador ácido-base natural que é o repolho roxo da espécie Brassica oleracea, uma variedade peculiar de couve. Foi utilizado esse indicador natural devido à sua comprovada eficácia para a distinção do $\mathrm{pH} \cdot{ }^{26}$

Os materiais utilizados além do repolho roxo foram: ácido acético (vinagre), álcool etílico hidratado $70^{\circ}$ INPM, água filtrada e hipoclorito de sódio (água sanitária, desinfetante de uso doméstico). Apesar de este experimento ser realizado em um laboratório, os materiais utilizados foram utensílios simples, como copos com medição de volume, e tubos de plástico transparente (tubetes) com tampa, ao invés de tubos de ensaio convencionais, e também foi confeccionada uma grade de isopor para inserir os tubos e minimizar ainda mais os custos com os experimentos.

O extrato de repolho roxo foi realizado da seguinte maneira: cortou-se o repolho em pequenas tiras, colocando-as em um frasco de vidro transparente com água filtrada até cobri-las. A mistura foi fervida até que a água fosse reduzida à metade do volume inicial. Com o auxílio de uma peneira, a solução foi extraída. Para a conservação, o extrato deve ser armazenado em temperatura de $10^{\circ} \mathrm{C}$ ou ainda, congelado. ${ }^{26} \mathrm{O}$ restante foi descartado.

Para o preparo de diferentes valores de $\mathrm{pH}$, foi utilizado o método de Antunes et al. ${ }^{26}$ com modificações. Para o preparo da solução, com o $\mathrm{pH}$ de aproximadamente 3,0, foram utilizados 5,0 $\mathrm{mL}$ de água filtrada e 5,0 mL do extrato do repolho roxo (1:1), com 10 gotas de ácido acético. 
Para um pH aproximado de 4,0, a solução acima foi diluída em 1:2 da concentração inicial, isso é, 5,0 mL da solução anterior foram adicionados a 5,0 $\mathrm{mL}$ de água, e a concentração de ácido acético foi reduzida para a metade da inicial (5 gotas). Para obtenção do $\mathrm{pH}$ aproximado de 5,0, a solução foi diluída novamente, utilizando os mesmos critérios descritos acima. O volume final de cada valor de $\mathrm{pH}$ foi de 5,0 mL.

Para obtenção de um $\mathrm{pH}$ próximo de 6,0 , utilizaram-se $2,5 \mathrm{~mL}$ de álcool etílico hidratado $70^{\circ}$ INPM e também $2,5 \mathrm{~mL}$ do extrato de repolho roxo (1:1). Já para o $\mathrm{pH}$ próximo de 7,0, foi utilizada água filtrada com o extrato de repolho roxo (1:1).

$\mathrm{O}$ pH aproximado de 12,0 foi obtido utilizando-se uma solução de hipoclorito de sódio com o extrato do repolho roxo (1:1) e os demais pHs aproximados de 9,0, 10,0 e 11,0 foram obtidos por meio da diluição seriada desse ( $\mathrm{pH} 12,0)$. Os pHs das soluções foram confirmados utilizando-se o método do eletrodo de vidro ( $\mathrm{KCl} / \mathrm{Ag}$ saturado), com sistema microprocessado e calibração em tampões 4,0 e 7,0. O aparelho utilizado foi o INSTRUTHERM, pHmetro PH - 2000, comprovando a aproximação do $\mathrm{pH}$ das soluções realizadas, com o valor real desejado. Esse método foi utilizado apenas para confirmação, não sendo necessário seu uso no desenvolvimento da aula prática. Tanto para o ensino médio, quanto para os anos iniciais de graduação, o preparo do extrato de repolho roxo é uma ótima oportunidade para trabalhar o tema diluição de solução, volumetria de complexação, titulação, diferentes indicadores de pHs naturais, metalocrômicos (que formam quelatos com íons metálicos) e indicadores artificiais.

Para a determinação do $\mathrm{pH}$ aproximado das amostras de solo, utilizou-se $1 \mathrm{~g}$ de solo juntamente com $10,0 \mathrm{~mL}$ do extrato de repolho roxo. Em seguida a solução foi agitada, manualmente, e um tempo de aproximadamente $10 \mathrm{~min}$ foi aguardado para ocorrer a decantação das partículas de solo. Após esse tempo, as partículas de solo foram decantadas, e a coloração da solução foi alterada e comparada com a faixa de $\mathrm{pH}$, obtida com o extrato de repolho roxo. ${ }^{26}$

\section{Análise microbiológica do solo}

\section{Determinação da população microbiana do solo}

Para a determinação da população microbiana do solo, utilizou-se um caldo como pré-enriquecimento, o mesmo foi preparado utilizando um tablete de caldo de carne industrializado em 250,0 mL de água filtrada (aproximadamente o volume de um copo), juntamente com $5,0 \mathrm{~g}$ de sal de cozinha (cloreto de sódio - $\mathrm{NaCl}$ ) (aproximadamente o volume de duas colheres de chá) e também 5,0 $\mathrm{g}$ de açúcar refinado (sacarose - $\mathrm{C}_{12} \mathrm{H}_{22} \mathrm{O}_{11}$ ).

Após o preparo da solução, a mesma foi fervida por $15 \mathrm{~min}$. A fervura não é um método de esterilização, porém pode matar diversos microrganismos ali presentes. ${ }^{6}$

Em seguida, a amostra de solo (25 g) foi colocada em contato com a solução ( pré-enriquecimento) em um recipiente transparente com tampa, com capacidade de 500,0 mL, desinfetado com álcool etílico hidratado $70^{\circ}$ INPM. ${ }^{6}$ Após vedar o recipiente, agitou-se manualmente a amostra por 2 minutos, com o movimento do braço perfazendo um ângulo de $90^{\circ}$.

Depois do preparo do meio de cultura líquido, continuou-se o experimento com a utilização de um meio de cultura sólido preparado com gelatina incolor e caldo de carne. ${ }^{6}$

O meio de cultura sólido foi vertido em placa de Petri de plástico doadas pelo laboratório da UTFPR, campus Apucarana. A limpeza das placas foi realizada, utilizando álcool etílico hidratado $70^{\circ}$ INPM. Para cada placa de Petri são necessários aproximadamente 20,0 mL de solução.

Os microrganismos da solução de pré-enriquecimento foram depositados sobre a placa de Petri contendo o meio de cultura já solidificado com a ajuda de hastes flexíveis com algodão na ponta. Após três dias, em temperatura ambiente, ocorreu o crescimento de microrganismos. Caso o laboratório possua uma estufa, este tempo pode ser minimizado $\left(24 \mathrm{~h}\right.$ a $\left.35 \pm 2{ }^{\circ} \mathrm{C}\right)$.

A solução feita de caldo de carne industrializado juntamente com sal de cozinha e açúcar, tem como propósito substituir a água peptonada tamponada $0,1 \%(\mathrm{p} / \mathrm{v})$, um meio de cultura líquido muito utilizado em matrizes alimentares com o mesmo objetivo, o pré-enriquecimento não seletivo de bactérias, como utilizado no trabalho de Cirolini et al. ${ }^{38}$

De acordo com as orientações da Instrução Normativa $n^{\circ} 62$, de 26 de agosto de $2003,{ }^{39}$ é possível enriquecer e extrair microrganismos, após a agitação da mistura, como coliformes totais e termotolerantes além de bactérias mesófilas, bolores e leveduras.

Essa mistura foi fervida representando um processo de pasteurização, destruição parcial de microrganismos patogênicos. Esse é um método eficiente, podendo substituir apenas em nível acadêmico o uso de autoclave (esterilização de materiais), equipamento de maior custo se comparado à chapa de aquecimento ou até mesmo um fogão.

O preparo do meio de cultura sólido consistiu na utilização de um pacote de gelatina incolor (agente solidificante) sob fervura, acrescentando um tablete de caldo de carne (substrato) e $250,0 \mathrm{~mL}$ de água filtrada. O tablete de caldo de carne pode ser substituído por sangue bovino, adquirido facilmente em açougue.

No lugar das placas de Petri de plástico podem ser utilizadas duas tampas finas transparentes ou ainda dois frascos rasos, ambos previamente tratados com álcool etílico hidratado $70^{\circ}$ INPM. As hastes flexíveis com algodão na ponta foram utilizadas como substituta do swab, que mesmo sendo de fácil acesso, pode não ser encontrado em laboratório de ensino, mas, caso o laboratório possua, indica-se o uso do swab por ser de mais fácil manuseio devido à sua haste ser maior.

Ao encontrarem um ambiente enriquecido - capaz de fornecer nutrientes e também condições para o desenvolvimento - os microrganismos se reproduzem excessivamente e aparecem sobre a superfície da placa. Esses ambientes podem também ser alimentos mal embalados ou guardados em local inadequado. É importante ressaltar aos alunos que nem sempre os microrganismos encontrados no solo são patogênicos, muitos são benéficos à nossa saúde e também para a sobrevivência de outros seres vivos.

\section{Extração de DNA dos microrganismos}

A extração do DNA genômico foi realizada por meio do método de fervura, ${ }^{40}$ com modificações. Para tanto, os microrganismos isolados foram extraídos do meio de cultura sólida com a ajuda de uma agulha de crochê (aquecida apenas sua ponta diretamente ao fogo por aproximadamente $30 \mathrm{~s}$ ).

Esses isolados foram depositados em um eppendorf com 2,0 mL de água filtrada. ${ }^{40}$ Após esse preparo, agitou-se manualmente o eppendorf por $30 \mathrm{~s}$ para que as colônias se dissolvessem na água. Em seguida, a suspensão foi aquecida em banho-maria até a temperatura de fervura da água $\left(100^{\circ} \mathrm{C}\right)$ por $20 \mathrm{~min}$. Após essa etapa, a solução foi submetida a um banho de gelo, com o objetivo de cessar a reação. Em seguida, foi adicionado $0,5 \mathrm{~mL}$ de álcool etílico hidratado $70^{\circ} \mathrm{INPM}$ (temperatura de aproximadamente $4^{\circ} \mathrm{C}$ ) pelas paredes do eppendorf, separando, assim, o DNA (extraído dos microrganismos) da solução. O sobrenadante foi visualizado com a ajuda de um palito de madeira, sendo, aquele, um líquido extremamente viscoso e translúcido.

\section{Sugestões}

A extração dos microrganismos isolados que se desenvolveram na placa de Petri geralmente é feita com o auxílio de alças de semeadura, porém, na falta destas, pode-se utilizar uma agulha de crochê, como 
no presente trabalho. Também é possível produzir manualmente uma alça de semeadura, moldando um fio fino de ferro, formando um círculo na ponta que permita a coleta.

Outro método que pode ser utilizado para a extração do DNA, seria pela quebra da parede celular com uma ação mecânica causada pelo carbonato de silício, dióxido de silício (sílica), ou ainda utilizando areia. Na falta de banho-maria ou bico de Bunsen para a elevação da temperatura e extração do DNA, ambos os métodos descritos, podem ser utilizados para o rompimento da parece celular e liberação do DNA.

Esse produto (carbonato de silício) apresenta granulometria em torno de $320 \mathrm{~mm}$ e é quimicamente inerte e o DNA pode ser extraído por meio de agitação para o rompimento da parede celular. ${ }^{41}$ Todos os métodos propostos foram executados com sucesso no presente trabalho.

No lugar do eppendorf poderia ser utilizado um tubo de ensaio micro, ou ainda frascos de plástico destinados ao uso de amostras de perfume, mas o eppendorf é de fácil acesso, encontrado em embalagens com 1000 unidades custando menos de trinta reais.

Segundo Marques e Suzart, ${ }^{40}$ a utilização do álcool etílico hidratado $70^{\circ} \mathrm{INPM}$ em temperatura de $4{ }^{\circ} \mathrm{C}$, substitui a centrifugação necessária para separar o DNA dos microrganismos, o que se daria por $10 \mathrm{~min}$ a $10.000 \mathrm{rpm}$, mas, caso o laboratório seja equipado com uma centrífuga a sua utilização é sugerida.

\section{RESULTADOS E DISCUSSÕES}

Após a coleta, as amostras passaram pelo método de catação para a separação. Foi possível observar que o solo coletado continha muitas impurezas como pedregulhos, galhos e folhas. Essa característica está relacionada com o solo de superfície, pois quanto mais profundo se faz a coleta menos impurezas são encontradas. A composição mineral argilosa, a capacidade de troca catiônica e o tamanho das partículas contribuem para as características de sedimentação dos solos. ${ }^{42,43}$ Após a retirada das impurezas do solo, foram verificadas as suas fases.

A Figura 1, mostra os torrões de três pontos de coleta submersos na água com as bolhas de ar saindo dos mesmos (indicação pelas setas pretas). Após 10 min com agitação, a água apresentou uma coloração marrom com o esfacelamento do torrão (a seta azul indica a mudança de coloração). É importante verificar que em cada ponto o solo apresenta-se com uma característica diferente, submetido ao mesmo processo.

\section{Sugestões}

O professor pode usar esse resultado para mostrar a importância do ar para os microrganismos, às raízes das plantas e aos pequenos animais.

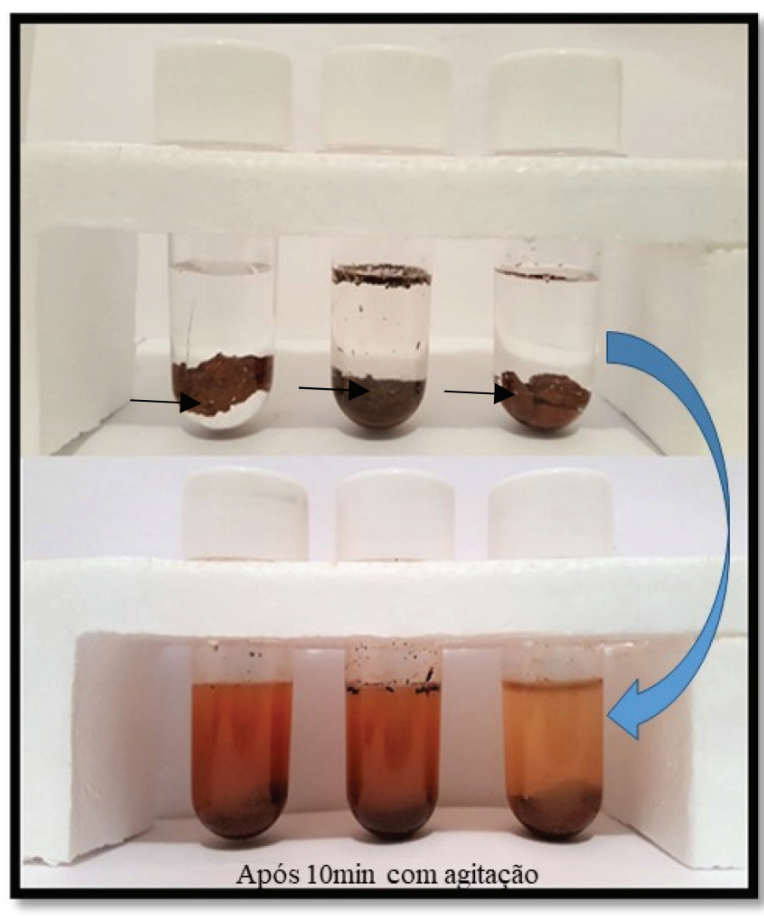

Figura 1. Verificação das diferentes fases do solo

Por extensão, o fato de o torrão se dissolver na água, pode ser usado como analogia para explicar o efeito das gotas de chuva sobre os solos. A cor barrenta da água pode ser usada para explicar como as águas de rios ficam barrentas após a precipitação.

Após a verificação das fases do solo, o pH foi determinado e comparado com a faixa do extrato de repolho roxo demonstrado na Figura 2.

O principal pigmento solúvel em água, sensível ao $\mathrm{pH}$ do extrato repolho roxo é a antocianina, e ela atua como indicador pois, reage com íons $\mathrm{H}^{+}$ou $\mathrm{OH}^{-}$que estão presentes em várias soluções adicionadas ao extrato e, dependendo do $\mathrm{pH}$, as soluções mudam de cor. ${ }^{26}$

A Figura 3 ilustra a coloração obtida quando adicionado o extrato do repolho roxo ao solo, a mesma apresenta o resultado dos três pontos escolhidos aleatoriamente em nível de ilustração para a coleta das amostras.

Comparando com a faixa de $\mathrm{pH}$ do extrato de repolho roxo, as amostras de solo analisadas apresentaram um $\mathrm{pH}$ de aproximadamente 6,0 (coloração roxa). Dessa forma, as amostras possuem um caráter levemente ácido, e isso quer dizer que a concentração de íons $\mathrm{H}^{+}$é superior à concentração de íons $\mathrm{OH}^{-}$. Os solos podem apresentar esse caráter naturalmente, em função da própria pobreza em bases, devido,

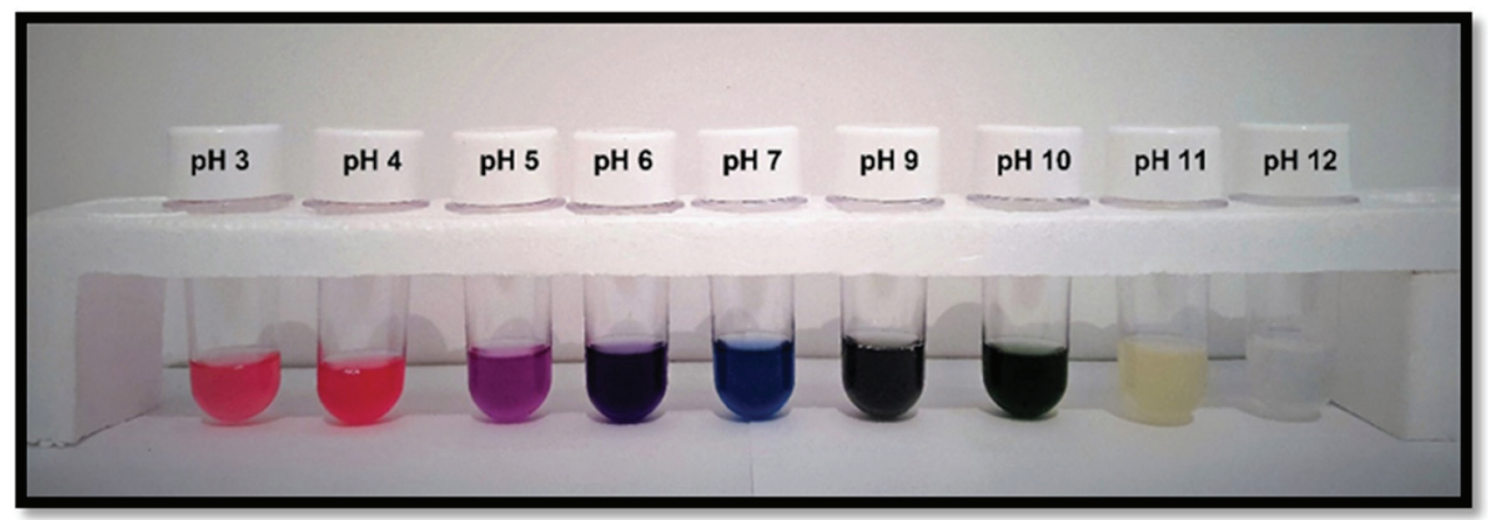

Figura 2. Soluções contendo extrato de repolho roxo como indicador universal de pH 


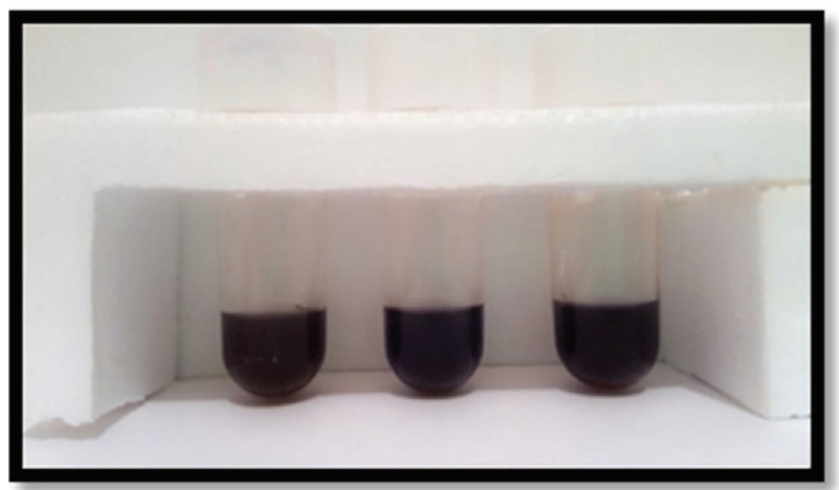

Figura 3. pH do solo com a utilização do extrato de repolho roxo

principalmente, a processos de formação que favorecem a remoção de $\mathrm{K}^{+}, \mathrm{Na}^{+}, \mathrm{Mg}^{2+}, \mathrm{Ca}^{2+}$ entre outros elementos básicos. ${ }^{44}$

De acordo com Antunes et al. ${ }^{26}$ quando trabalharam com os alunos de ensino médio questões relacionadas ao $\mathrm{pH}$ do solo, observaram que a maior dificuldade encontrada pelos alunos foi em relação às questões que estabeleceram a multidisciplinaridade envolvendo a Química e a Biologia. Nesse contexto, com o presente estudo, esse problema é solucionado já que os experimentos demonstrados estão levando em consideração a multidisciplinaridade dessas duas disciplinas.

Já, em relação à população microbiana encontrada no solo, observa-se na Figura 4 que, dependendo do solo analisado, ocorrerá maior ou menor crescimento de microrganismos. Essa discussão é muito importante, pois, dependendo das características do local e do clima da região, da umidade, concentração de íons de hidrogênio, composição de matéria orgânica, entre outros fatores, a população microbiana é alterada. Em tempos chuvosos há uma tendência no aumento de microrganismos quando comparada com dias sem precipitações pluviométricas devido à disponibilidade de umidade e carreamento de detritos para o solo. Outro fator importante que regula a atividade microbiana seria a disponibilidade de nutrientes existentes em diferentes tipos de solos. ${ }^{45,46}$
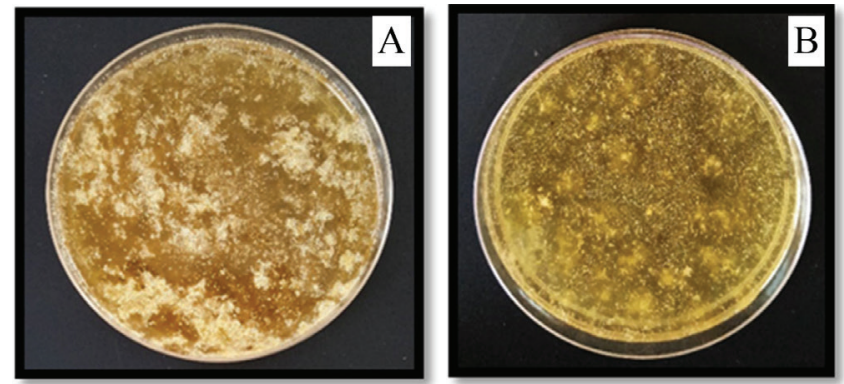

Figura 4. População microbiana do ponto de coleta (A) e do ponto de coleta $(B)$

No estudo realizado por Gislin et al., ${ }^{47}$ eles isolaram bactérias de 10 locais diferentes em Kerala, Índia. Todas os microrganismos extraídos testados por caracterização morfológica apresentaram-se como Gram positivas. Dentre elas, seis são patógenos para o ser humano, como Escherichia coli, Enterococcus sp., Pseudomonas aeruginosa, Klebsiella pneumoniae, Staphylococcus aureus e Acinetobacter sp. Para comprovar essa patogenicidade, porém, é preciso analisar os genes de virulência e resistência a antibióticos em seu DNA, pois alguns desses microrganismos estão presentes naturalmente em nosso sistema digestivo.

Espécies do gênero Enterococcus também possuem como habitats naturais a superfície sólida da crosta terrestre. Collins et al. ${ }^{48}$ indicam que E. mundtii, possui habitat conhecido como solo e planta e $E$. casseliflavus, além desses, também habitam em animais diversos.

Os microrganismos ajudam na manutenção da estrutura do solo, pois ocorre a produção de substâncias mucilaginosas que auxiliam a agregar o solo, além de auxiliarem no desenvolvimento de plantas. ${ }^{49,50}$

Verificou-se que há uma maior população microbiana na Figura 4A, quando comparada à Figura 4B. Isso pode ser explicado pela provável falta de substratos no ponto de coleta da Figura 4B.

Os tipos de microrganismos encontrados no solo são os mais diversos possíveis e a quantidade é bastante elevada.

Após a verificação da população microbiana, o DNA foi extraído. Na Figura 5A é possível observar a separação de duas fases, em que o precipitado são as células destruídas pelo processo chamado de lise celular, e essa destruição ou dissolução da célula é causada pela ruptura da membrana plasmática e, com isso, ocorre a liberação do DNA (sobrenadante). O sobrenadante translúcido e viscoso, observado na Figura 5B (círculo preto), é o DNA liberado dos microrganismos. Os resultados obtidos foram satisfatórios, pois independentemente do método utilizado pôde-se observar separação de duas fases.
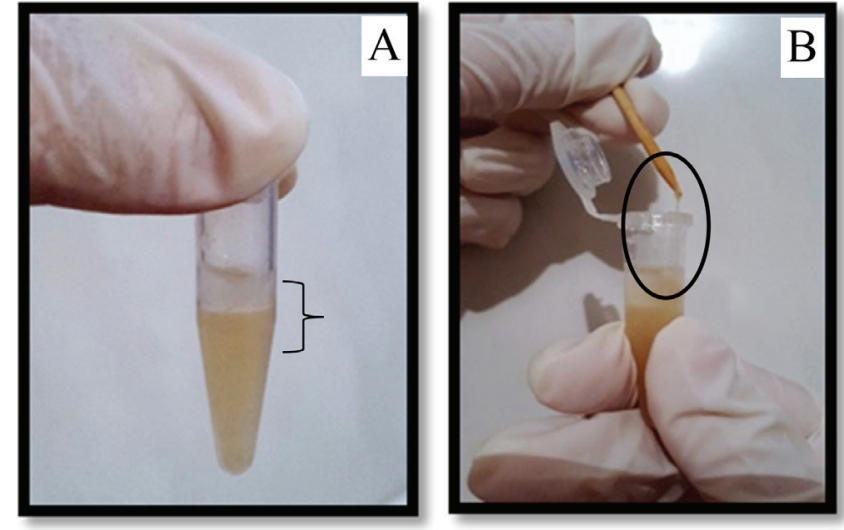

Figura 5. Separação do DNA extraído da população microbiana do solo (A) e detalhe do DNA liberado $(B)$

\section{CONCLUSÃO}

O presente trabalho relata o ensino na área de Química e Microbiologia/Biologia por meio de uma investigação científica: sequência didática, utilizando materiais de fácil acesso, como alternativa para avaliação do solo envolvendo a multidisciplinaridade. A falta de espaço físico e de recursos em escolas com ensino médio impulsionou esse trabalho a utilizar materiais de fácil acesso. Por outro lado, essa abordagem pode ser empregada também nos anos iniciais de graduação, principalmente em cursos de licenciatura em Química e Biologia, sendo uma proposta didática para futuros professores. A proposta de uma aula experimental, utilizando a determinação dos parâmetros físico-químicos e microbiológicos do solo, como foi demonstrado, abrange diferentes áreas do conhecimento. Dessa forma, a realização de uma aula experimental com materiais encontrados no dia a dia é possível, tornando o conhecimento mais palpável e simples. ${ }^{51}$ Os conceitos sobre os aspectos de fenômenos macroscópicos podem ser reforçados e levar, ainda, a reflexão dos aspectos microscópicos.

\section{AGRADECIMENTOS}

Os autores agradecem o apoio da Fundação ARAUCARIA, UEM e UTFPR. 


\section{REFERÊNCIAS}

1. Krasilchik, M.; Prática de Ensino de Biologia, 4ª ed., EDUSP: São Paulo, 2004

2. Andrade, M. L. F.; Massabni, V. G. O.; Ciência \& Educação 2011, 17, 835.

3. Bartzik, F.; Zander, L. D.; Revista @rquivo Brasileiro de Educação 2016, 4, 31 .

4. Vasconcellos, C. D. S.; Planejamento: plano de ensino: aprendizagem e projeto educativo, 4ª ed., Libertad: São Paulo, 1995.

5. Freitas, M. S.; Almeida, O. D. S.; Damasceno, I. T.; Sousa, A. O.; Santos, A. M.; Cercundo, G. S. S.; Barbosa, S. S.; Revista de Ensino de Biologia 2016, 9, 1759.

6. Walters, A. U. C.; Lawrence, W.; Jalsa, N. K.; Saf. Sci. 2017, 96, 161.

7. Stokols, D.; Fuqua, J.; Gress, J.; Harvey, R.; Phillips, K.; BaezcondeGarbanati, L.; Unger, J.; Palmer, P.; Clark, M. A.; Colby, S. M.; Morgan, G.; Trochim, W.; Nicotine Tob. Res. 2003, 5, 1.

8. Souza, J. I. R.; Leite, B. S.; Rev. Virtual Quim. 2018, 10, 4.

9. Ferreira, F. R.; Educação e Pesquisa 2010, 36, 1.

10. Sharma, A.; Jelemenský, M.; Valo, R.; Kalúz, M.; Fikar, M.; IFACPapersOnline 2016, 49, 4.

11. Dias, M. V.; Guimarães, P. I. C.; Merçon, F.; Quim. Nova Esc. 2003, 17, 27.

12. Visentainer, J. V.; Souza, N. E.; Visentainer, J. E. L.; Análises Químicas Qualitativas em Alimentos: Experimentos Laboratoriais Explicativos $e$ de Fácil Realização, utilizando Alimentos, Enzimas e Reagentes do Cotidiano, $1^{\text {a }}$ ed., EDUEM: Maringá, 2011.

13. Gómez-Brandón, M.; Juárez, M. F. D.; Insam, M. Z. H.; J. Hazard. Mater. 2016, 302, 267.

14. Oliveira, J. R. S.; Acta Sci. 2010, 12, 139.

15. Hartemink, A. E.; Balks, M. R.; Chen, Z. S.; Drohan, P.; Field, D. J.; Krasilnikov, P.; Lowe, D. J.; Rabenhorst, M.; Rees, K. V.; Schad, P.; Schipper, L. A.; Sonneveld, M.; Walter, C.; Geoderma 2014, 217, 218.

16. Ferreira, M. P.; Suzuki, R. M.; Bonafe, E, G.; Matsushita, M.; Berton, S. B. R.; Rev. Virtual Quim. 2019, 11, 3.

17. Viana, L. Z. S.; Vaz, M. D.; Giacon, E. M. O.; Pinto, M. L.; Freitas, S. A.; Revista Philologus. 2014, 60, 2003.

18. Suart, R. de C.; Marcondes, M. E. R.; Ciência \& Cognição. 2009, 14, 50 .

19. Santos, E. S.; Zanello, S.; Programa de Desenvolvimento Educacional (PDE) - Centro Estadual de Educação Profissional Newton Freire Maia, $1^{\mathrm{a}}$ ed., Pinhais: Brasil, 2009.

20. Fisher, R. R.; Fox, T. R.; Harrison, R. B.; Terry, T.; For. Ecol. Manage. 2005, 220, 3

21. Silva, J. N.; Amorim, J. S.; Monteiro, L. P.; Freitas, K. H. G.; Sci. Plena. 2017, 13, 1 .

22. Oliveira, C. A. F.; Resende Filho, J. B. M.; Andrade, L. R.; Quim. Nova Esc. 2011, 33, 125.

23. Vollmer, A. C.; Teaching Resources, Microbiology: Encyclopedia of Microbiology, $3^{\text {a }}$ ed., Elsevier: USA, 2009.

24. Abramo, G.; D’Angelo, C. A.; Zhang, L.; Journal of Informetrics 2018, 4,12 .

25. http://portal.mec.gov.br, acessada em Março 2020.
26. Antunes, M.; Adamatti, D. S.; Pacheco, M. A.; Giovanella, M.; Quim. Nova Esc. 2009, 31, 283.

27. Guo, W.; Mathias, N. A.; Qi, X. B.; Li, P.; Li, Z. Y.; Fan, X. Y.; Zhou, Y.; J. Integr. Agric. 2017, 16, 679.

28. Sauze, J.; Ogée, J.; Maron, P. A.; Crouzet, O.; Nowak, V.; Wohl, S.; Kaisermann, A.; Jones, S. P.; Wingate, L.; Soil Biol. Biochem. 2017, $115,371$.

29. Griffiths, R. I.; Thomson, B. C.; James, P.; Bell, T.; Bailey, M.; Whiteley, A. S.; Environ. Microbiol. 2011, 13, 1642.

30. Normark, B. H.; Normark, S.; J. Intern. Med. 2002, 252, 91.

31. Sousa, R. S.; Rocha, P. D. P.; Garcia, I. T. S.; Quim. Nova Esc. 2012, 34, 220.

32. Guerra, A.; Freitas, J.; Reis, J. C.; Braga, M. A.; Caderno Brasileiro de Ensino de Física 1998, 15, 32.

33. Tavares, W.; Revista da Sociedade Brasileira de Medicina Tropical 2000, $33,281$.

34. Silva, M.; Rev. Interdisc. 2017, 10, 59.

35. Bastos, A. R.; Quim. Nova 2015, 38, 749

36. Villa Nova, N. A.; Bacchi, O. O. S.; Reichardt, K.; Sci. Agric. (Piracicaba, Braz.) 1996, 53, 1.

37. https://www.embrapa.br/solos/sibcs, acessada em Março 2020.

38. Cirolini, A.; Fries, L. L. M.; Terra, N. M.; Milani, L. I. G.; Urnau, D.; Santos, B. A. dos.; Cervo, G. D.; Rezer, A. P.; Cienc. Tecnol. Aliment. (Campinas, Braz.) 2010, 30, 171.

39. https://www.defesa.agricultura.sp.gov.br/legislacoes/instrucaonormativa-sda-62-de-26-08-2003,665.html, acessada em Março 2020.

40. Marques, E. B.; Suzart, S.; J. Med. Microbiol. 2004, 53, 1069.

41. Rosa, D. D.; Summa Phytopathol. 2008, 34, 259.

42. Bakir, H.; Zhang, Z.; Zbik, M. S.; Harrison, M. D.; Doherty, W. O. S.; J. Food Eng. 2016, 189, 55.

43. Hicks, L. C.; Meir, P.; Nottingham, A. T.; Reay, D. S.; Stott, A. W.; Salinas, N.; Whitaker, J.; Soil Biol. Biochem. 2019, 129, 212.

44. Lopes, A. S.; Silva, M. C.; Guilherme, L. R. G.; Boletim técnico $n^{\circ} 1$ : acidez do solo e calagem., $3^{\mathrm{a}}$ ed., ANDA: São Paulo, 1991.

45. Nunes, R. R.; Benetti, F.; Pigatin, L.B. F.; Martelli, L. F. A.; Rezende, M. O. O.; Rev. Virtual Quim. 2014, 6, 478.

46. Duarte, L. A.; Rosário, D. K.; Oliveira, B. S.; Souza, H. L.; Carvalho, R. V.; Carneiro, J. C. S.; Silva, P. I.; Bernardes, P. C.; Int. J. Food Microbiol. 2018, 269, 12.

47. Gislin, D.; Sudarsanam, D.; Ray, G. A.; Baskar, K.; J. Genet. Eng. Biotechnol. 2018, 16, 287.

48. Collins, M. D.; Farrow, J. A. E.; Jones, D.; Int. J. Syst. Bacteriol. 1986, 36,8 .

49. Roberto, S. B.; Berton Junior, J.; Suzuki, R. B.; Bonafé, E. G.; Matsushita, M.; Canesin, E. A. Em Princípios de Química; Voigt, C. L., org.; Atena Editora: Ponta Grossa, 2019, cap. 24.

50. Berton, S. B. R.; de Jesus, G. A. M.; Sabino, R. M.; Monteiro, J. P.; Venter, S. A. S.; Bruschi, M. L.; Popat, K. C.; Matsushita, M.; Martins, A. F.; Bonafé, E. G.; Carbohydr. Res. 2020, 487, 107883.

51. Berton, S. B. R.; Roberto, M. C. B.; Becel, L. A.; Matsushita, M.; Bonafé, E. G.; Ferreira, M. P. Em As Ciências Exatas e da Terra e a Interface com vários Saberes; Pereira, A. I. A., eds.; Atena Editora: Ponta Grossa, 2019, cap. 13. 